\title{
Hepatic lipogenesis in young rats given proteins of different quality
}

\author{
BY G. R. HERZBERG AND MINDA ROGERSON \\ Department of Biochemistry, Memorial University of Newfoundland, St John's, \\ Newfoundland $A 1 B 3 \times 9$, Canada
}

(Received 2 September 1983 - Accepted 30 January 1984)

\begin{abstract}
1. The effect of feeding casein, lactalbumin, soya-bean protein, gluten or gelatin on hepatic lipogenesis and the levels of hepatic fatty acid synthetase (FAS), glucose-6-phosphate dehydrogenase (EC 1.1 1 1.49; G6PD), malic enzyme (EC 1.1.1.40; ME) ATP-citrate lyase $(E C$ 4.1.3.8; CL), acetyl CoA carboxylase $(E C$ 6.4.1.2; $A C C x)$ and glucokinase $(E C 2.7 .1 .2 ; G K)$ was examined in young growing rats.

2. The total activities of ACCx, FAS, CL, GK, G6PD, GK, ME and fatty acid synthesis in vivo were positively correlated with protein quality.

3. The specific activities of ACCx, FAS, CL, G6PD and fatty acid synthesis in vivo were positively correlated with protein quality.

4. The specific activities of GK and ME were unrelated to protein quality.

5. The results demonstrate a dissociation between $\mathrm{ME}$ and hepatic lipogenesis and suggest a role for the NADPH generated by ME which is not related to the needs of fatty acid synthesis.
\end{abstract}

The role of dietary composition in the regulation of hepatic fatty acid synthesis has been the subject of numerous investigations. Both the composition and level of carbohydrate, fat and protein have been demonstrated to alter the rate of fatty acid synthesis and the activities of the associated enzymes (Romsos \& Leveille, 1974).

Hepatic fatty acid synthesis and the associated enzymes are inhibited by increased dietary fat, and this effect is more pronounced when polyunsaturated instead of saturated fatty acids are given (Herzberg, 1983). Increased dietary carbohydrate results in increased fatty acid synthesis and increased activities of the associated enzymes (Romsos \& Leveille, 1974). The type of carbohydrate also affects hepatic fatty acid synthesis (Herzberg \& Rogerson, 1982).

The role of dietary protein in the regulation of hepatic fatty acid synthesis has been studied much less than either dietary fat or carbohydrate. Yeh \& Leveille (1969) reported decreased chicken hepatic lipogenesis with increased dietary protein. This was accompanied by a decrease in malic enzyme (EC 1.1.1.40; ME). Peret et al. (1975) and Herzberg \& Rogerson (1981) observed decreased rat liver ME with increased dietary protein. Herzberg \& Rogerson (1981) also observed that the activities of acetyl CoA carboxylase (EC 6.4 1.2; ACCX), fatty acid synthetase (FAS), glucose-6-phosphate dehydrogenase (EC 1.1 1. 1.49; G6PD), ATP-citrate lyase ( $E C$ 4 $1.3 .8 ; C L)$ and in vivo fatty acid synthesis increased with dietary protein up to $100 \mathrm{~g}$ casein $/ \mathrm{kg}$ diet. This was also the concentration of casein which resulted in maximal growth.

The experiments reported in this paper were conducted to determine whether the association of fatty acid synthesis and dietary protein content previously reported is a result of the amount of protein in the diet or a result of the effect of protein quality on growth rate. In these experiments a single level of dietary protein was used and growth rate altered by using proteins of varying quality.

\section{MATERIALS AND METHODS}

Male weanling Sprague Dawley rats obtained from Canadian Breeding Labs, LaPrarie, Quebec were used. The average weight of the rats was $61.9 \mathrm{~g}$ on the first day of the experiment. The rats were distributed so that each treatment group had a similar initial 
Table 1. Composition $(\mathrm{g} / \mathrm{kg})$ of the experimental diets

\begin{tabular}{lrll}
\hline \hline Dextrose & 770 & AIN vitamin mix & 10 \\
Protein & 100 & Choline chloride & 02 \\
Cellulose $^{*}$ & 50 & DL-methionine & 03 \\
AIN mineral mix $\dagger$ & 35 & Maize oil & 30 \\
\hline
\end{tabular}

* Casein, lactalbumin, soya-bean protein, gluten or gelatin obtained from ICN Nutritional Biochemicals, Cleveland, Ohio.

$\dagger$ Obtained from ICN Nutritional Biochemicals, Cleveland, Ohio and had the following composition $(\mathrm{g} / \mathrm{kg})$ : $\mathrm{CaHPO}_{4} 500, \mathrm{NaCl} 74 \cdot 0$, potassium citrate monohydrate $220 \cdot 0, \mathrm{~K}_{2} \mathrm{SO}_{4} 52 \cdot 0, \mathrm{MgO}_{24} \cdot 0, \mathrm{MnCO}_{3} 3 \cdot 5$, ferric citrate $6.0, \mathrm{ZnCO}_{3} 1 \cdot 6, \mathrm{CuCO}_{3} 0.3, \mathrm{KIO}_{3} 0.01, \mathrm{NA}_{2} \mathrm{SeO}_{3} .5 \mathrm{H}_{2} \mathrm{O} 0.01, \mathrm{CrK}\left(\mathrm{SO}_{4}\right)_{2} .12 \mathrm{H}_{2} \mathrm{O} 0.55$, sucrose, 118.0 .

\$ Obtained from ICN Nutritional Biochemicals, Cleveland, Ohio and had the following composition (mg/kg): thiamin hydroxychloride 600 , riboflavin 600 , pyridoxine hydrochloride 700 , nicotinic acid 3 , calcium-D-pantothenate $1 \cdot 6$, folic acid 200 , D-biotin 20 , cyanocobalamin 1 , retinyl palmitate 800 , DL- $\alpha$-tocopheryl acetate 20 , cholecalciferol $2 \cdot 5$, menaquinone $5 \cdot 0$, sucrose $972 \cdot 9 \mathrm{~g}$.

Table 2. Weight gain, liver characteristics, feed conversion efficiency and protein efficiency ratio $(P E R)$ in young rats given proteins of different quality

\begin{tabular}{lcccccc}
\hline \hline \multicolumn{1}{c}{ Protein in diet... } & Casein & Lactalbumin & $\begin{array}{c}\text { Soya-bean } \\
\text { protein }\end{array}$ & Gluten & Gelatin & Pooled SE \\
\hline Wt gain (g) & $171^{\mathrm{a}}$ & $154^{\mathrm{ab}}$ & $121^{\mathrm{c}}$ & $22^{\mathrm{d}}$ & $-4^{\mathrm{e}}$ & $4 \cdot 6$ \\
Relative liver wt* & $4 \cdot 40^{\mathrm{a}}$ & $4 \cdot 07^{\mathrm{abc}}$ & $3 \cdot 86^{\mathrm{bc}}$ & $3 \cdot 74^{\mathrm{c}}$ & $3 \cdot 84^{\mathrm{bc}}$ & $0 \cdot 16$ \\
DNA (mg/g liver) & $1 \cdot 34^{\mathrm{ab}}$ & $1 \cdot 32^{\mathrm{ab}}$ & $1 \cdot 50^{\mathrm{a}}$ & $0 \cdot 87^{\mathrm{b}}$ & $1 \cdot 62^{\mathrm{a}}$ & $0 \cdot 11$ \\
Lipid (mg/g liver) & $6 \cdot 91^{\mathrm{ab}}$ & $55 \cdot 0^{\mathrm{bc}}$ & $61 \cdot 7^{\mathrm{bc}}$ & $94 \cdot 5^{\mathrm{a}}$ & $44 \cdot 2^{\mathrm{a}}$ & $5 \cdot 6$ \\
Feed conversion efficiency $\dagger$ & $31 \cdot 7^{\mathrm{a}}$ & $29 \cdot 4^{\mathrm{ab}}$ & $24 \cdot 8^{\mathrm{c}}$ & $5 \cdot 1^{\mathrm{d}}$ & $-0 \cdot 7^{\mathrm{e}}$ & $0 \cdot 9$ \\
PER $\neq$ & $3 \cdot 17^{\mathrm{a}}$ & $2 \cdot 94^{\mathrm{ab}}$ & $2 \cdot 48^{\mathrm{c}}$ & $0 \cdot 51^{\mathrm{d}}$ & $0 \cdot 07^{\mathrm{e}}$ & $0 \cdot 09$ \\
\hline
\end{tabular}

* (Liver weight/body-weight) $\times 100$.

$\dagger$ (g weight gained $/ \mathrm{g}$ feed consumed) $\times 100$.

$\$ \mathrm{~g}$ weight gained/g protein consumed.

$\mathbf{a}, \mathbf{b}, \mathfrak{c}, \mathrm{d}, \mathrm{e}$ Values in the same horizontal row with different superscript letters were significantly different: $P<0.05$.

average body-weight. Four rats were included in each treatment group. The animals were maintained in a light-controlled (light between 08.00 and 21.00 hours) room at a temperature of approximately $23^{\circ}$. Food and water were available ad lib. The animals were housed individually in metabolic cages. Animal weight and food consumption were determined daily. The composition of the diets is given in Table 1. The animals were given the experimental diets for $35 \mathrm{~d}$. In each experiment twenty rats were used; four rats received each experimental diet. Two experiments were conducted and the results combined. As a result a total of eight rats received each experimental diet.

On the morning of the 35th day, the animals were injected intraperitoneally with $500 \mu \mathrm{Ci}$ of ${ }^{3} \mathrm{H}_{2} \mathrm{O}$ and were decapitated 60 min later. A sample of blood was taken for determination of plasma specific radioactivity. The liver was rapidly removed and a portion homogenized in cold $0.15 \mathrm{M}$-potassium chloride, $1.0 \mathrm{~mm}$-magnesium chloride, $0.5 \mathrm{~mm}$-dithiothreitol and $10 \mathrm{~mm}-\mathrm{N}$-acetyl cysteine buffer ( $\mathrm{pH} 7 \cdot 6$ ).

Following centrifugation at $100000 \mathrm{~g}$ for $40 \mathrm{~min}$, the supernatant fraction was used for quantitative determination of enzyme activities. FAS was determined by following the rate of malonyl-CoA-dependent NADPH oxidation (Gibson \& Hubbard, 1960); G6PD by following the rate of glucose-6-phosphate-dependent reduction of NADP (Lohr \& Waller, 1971); ME by following the rate of malate-dependent NADP reduction (Yeh et al. 1970); 
Table 3. Hepatic enzyme activities and lipogenesis in vivo measured in young rats given proteins of different quality

\begin{tabular}{|c|c|c|c|c|c|c|}
\hline Protein in diet. & ... Casein & Lactalbumin & $\begin{array}{c}\text { Soya-bean } \\
\text { protein }\end{array}$ & Gluten & Gelatin & Pooled SE \\
\hline & \multicolumn{6}{|c|}{ Specific activity (nmol/mg liver per min) } \\
\hline $\mathrm{ACCx}$ & $2.93^{a}$ & $2 \cdot 92^{\mathrm{a}}$ & $2 \cdot 27^{a b}$ & $2 \cdot 13^{\mathrm{ab}}$ & $0.97^{b}$ & 0.58 \\
\hline FAS & $26 \cdot 2^{\mathrm{a}}$ & $29 \cdot 5^{a}$ & $23 \cdot 8^{a}$ & $11 \cdot 4^{b}$ & $12 \cdot 4^{b}$ & $2 \cdot 4$ \\
\hline $\mathrm{CL}$ & $96 \cdot 8^{\mathrm{a}}$ & $81 \cdot 7^{\mathrm{a}}$ & $81 \cdot 9^{\mathrm{a}}$ & $48 \cdot 1^{\mathrm{a}}$ & $49 \cdot 7^{b}$ & $7 \cdot 1$ \\
\hline GK & $54 \cdot 7$ & $48 \cdot 2$ & 58.8 & 47.2 & $46 \cdot 4$ & 4.0 \\
\hline G6PD & $115^{\mathrm{ab}}$ & $84^{\mathrm{bc}}$ & $79^{\mathrm{bc}}$ & $57^{c}$ & $51^{\mathrm{c}}$ & 13.4 \\
\hline $\mathrm{ME}$ & $74^{\mathrm{d}}$ & $80^{\mathrm{ed}}$ & $115^{\mathrm{abc}}$ & $123^{a b}$ & $90^{\text {bed }}$ & $11 \cdot 2$ \\
\hline \multirow{2}{*}{$\begin{array}{l}\text { Fatty acid synthesis } \\
\text { ( } \mu \text { mol }{ }^{3} \mathrm{H} \text { incorporated } \\
\text { into saponifiable } \\
\text { lipid/g liver per } h)\end{array}$} & $48 \cdot 0^{\mathrm{a}}$ & $50 \cdot 4^{2}$ & $55 \cdot 0^{\mathrm{a}}$ & $25 \cdot 9 \mathrm{~b}$ & $24 \cdot 3^{b}$ & $10 \cdot 6$ \\
\hline & \multicolumn{6}{|c|}{ Total activity ( $\mu \mathrm{mol} /$ liver per min) } \\
\hline $\mathrm{ACCx}$ & $2 \cdot 19^{\mathrm{a}}$ & $2 \cdot 17^{\mathrm{a}}$ & $1 \cdot 24^{\mathrm{ab}}$ & $0.35^{\mathrm{bc}}$ & $0 \cdot 16^{\mathrm{c}}$ & 0.35 \\
\hline FAS & $23 \cdot 8^{a}$ & $22 \cdot 5^{\mathrm{a}}$ & $1 \cdot 29^{\mathrm{b}}$ & $1 \cdot 8^{c}$ & $2 \cdot 0^{\mathrm{c}}$ & 0.4 \\
\hline $\mathrm{CL}$ & $88 \cdot 5^{\mathrm{ab}}$ & $72 \cdot 5^{b}$ & $45 \cdot 0^{\mathrm{b}}$ & $7 \cdot 4^{\mathrm{c}}$ & $8 \cdot 0^{c}$ & $9 \cdot 2$ \\
\hline GK & $48 \cdot 5^{a}$ & $36 \cdot 0^{b}$ & $30 \cdot 3^{b}$ & $7 \cdot 2^{\mathrm{c}}$ & $7 \cdot 4^{e}$ & $2 \cdot 9$ \\
\hline G6PD & $106 \cdot 6^{a}$ & $66 \cdot 6^{b}$ & $44 \cdot 0^{\mathrm{b}}$ & $8 \cdot 9^{\mathrm{c}}$ & $8 \cdot 6^{\mathrm{c}}$ & $12 \cdot 0$ \\
\hline ME & $68 \cdot 7^{\mathrm{ab}}$ & $51 \cdot 2^{b}$ & $61 \cdot 5^{b}$ & $20 \cdot 9^{\mathrm{e}}$ & $15 \cdot 0^{\mathrm{c}}$ & $7 \cdot 3$ \\
\hline $\begin{array}{l}\text { Fatty acid synthesis } \\
\text { ( } \mu \text { mol }{ }^{3} \mathrm{H} \text { incorporated } \\
\text { into saponifiable } \\
\text { lipid/liver per } \mathrm{h})\end{array}$ & $536^{\mathrm{a}}$ & $470^{\mathrm{a}}$ & $384^{a}$ & $79^{b}$ & $49^{b}$ & 110 \\
\hline
\end{tabular}

a,b.c,d Values on the same horizontal row with different superscript letters were significantly different: $P<0 \cdot 05$. $A C C x$, acetyl CoA carboxylase (EC 6.4 1.2); FAS, fatty acid synthetase; CL, ATP-citrate lyase (EC 4.1.3.8); GK, glucokinase (EC 2.7.1.2); G6PD, glucose-6-phosphate dehydrogenase (EC 1.1 1.49); ME, malic enzyme (EC 1.1.1.40).

glucokinase ( $E C 2.7 .1 .2$; GK) by following the rate of glucose-dependent reduction of NADP in the presence of added G6PD after correction for hexokinase activity (Pilkis, 1975); CL by the method of Srere (1959), and ACCx from the acetyl CoA-dependent incorporation of $\mathrm{H}^{14} \mathrm{CO}_{3}$ into acid-stable material (Gove \& Hems, 1978). With the exception of ACCx, enzyme activities were determined by continuous spectrophotometric methods.

A second portion of the liver was used to determine fatty acid synthesis in vivo (Lowenstein, 1971). The tissue was deposited directly into $5 \mathrm{M}$-potassium hydroxide and heated at $70^{\circ}$ for 3-4 h. After saponification, the samples were extracted with three $5 \mathrm{ml}$ portions of light petroleum (b.p. 37-8-56.1) to remove non-saponifiable lipid. The samples were then acidified with hydrochloric acid and the fatty acids extracted with three $5 \mathrm{ml}$ portions of light petroleum. The extracts were combined in a scintillation vial, the light petroleum evaporated and the radioactivity in the extracted fatty acids determined by liquid scintillation spectrometry. Protein was determined by the microbiuret method of Goa (1953) using bovine serum albumin as standard.

Total liver lipid was determined gravimetrically after extraction of a third portion of liver with chloroform-methanol $(2: 1, v / v)$. Significance of a treatment effect was determined by analysis of variance. Differences among treatments were determined by Duncan's new multiple-range test (Steel \& Torrie, 1960). Differences were considered significant if $P<0.05$. 


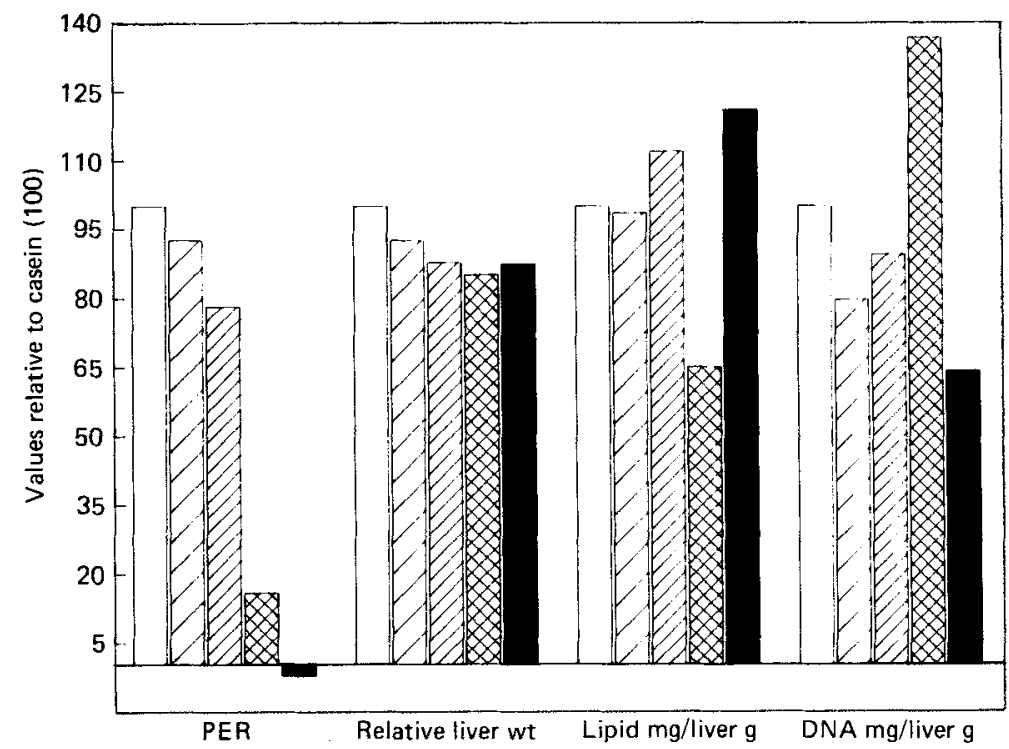

Fig. 1. Liver characteristics and protein efficiency ratio (PER;g weight gained/g protein consumed) in young rats given different proteins: $(\square)$, casein; ( $\square$ ), lactalbumin; ( $(Z)$, soya-bean protein; ( $)$, gluten; (D), gelatin. Values are expressed relative to casein (100). The unnormalized values are presented in Table 2.

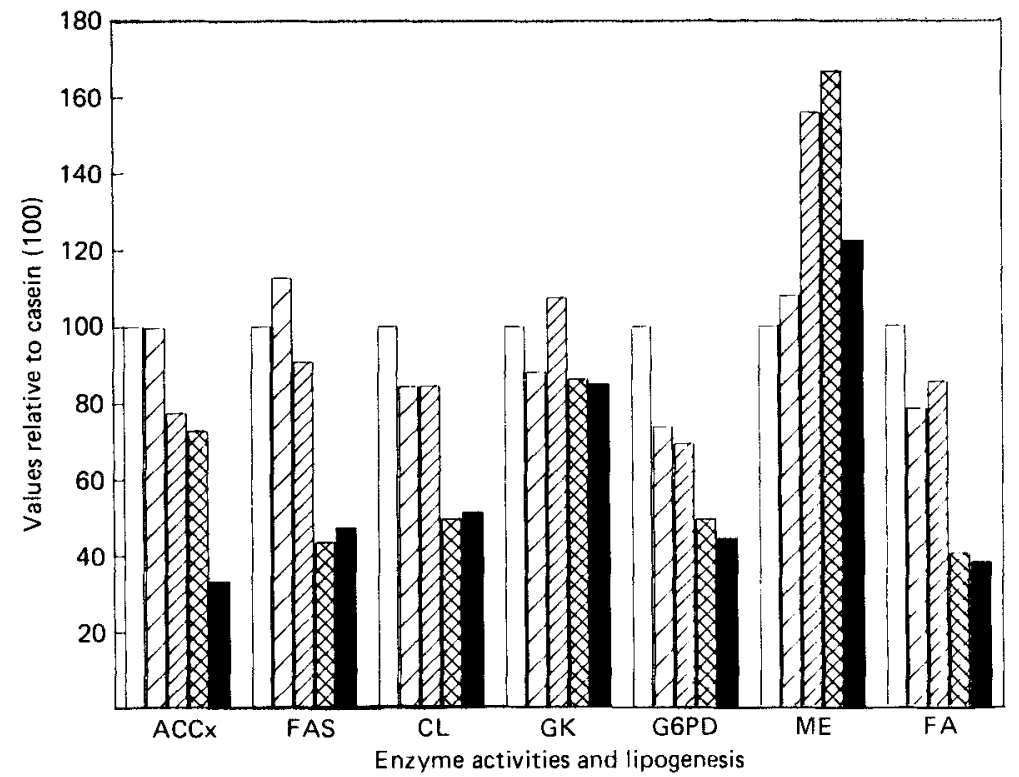

Fig. 2. Specific enzyme activities and lipogenesis in vivo (/g liver) in young rats given proteins of different quality: ( $\square$ ), casein; (巳d), lactalbumin; (囚), soya-bean protein; ( $)$, gluten; ( $\square$ ), gelatin. ACCx, acetyl CoA carboxylase (EC 6.4 1.2); FAS, fatty acid synthetase; CL, ATP-citrate lyase $(E C 4.1 .3 .8)$; GK, glucokinase (EC 2.7.1.2); G6PD, glucose-6-phosphate dehydrogenase (EC 1.1.1.49); ME, malic enzyme (EC 1 1 1 1 .40); FA, fatty acid synthesis $\left({ }^{3} \mathrm{H}\right.$ incorporated into saponifiable lipid/g liver per $\mathrm{h}$ ). Values are expressed relative to casein (100). The unnormalized values are presented in Table 3. 


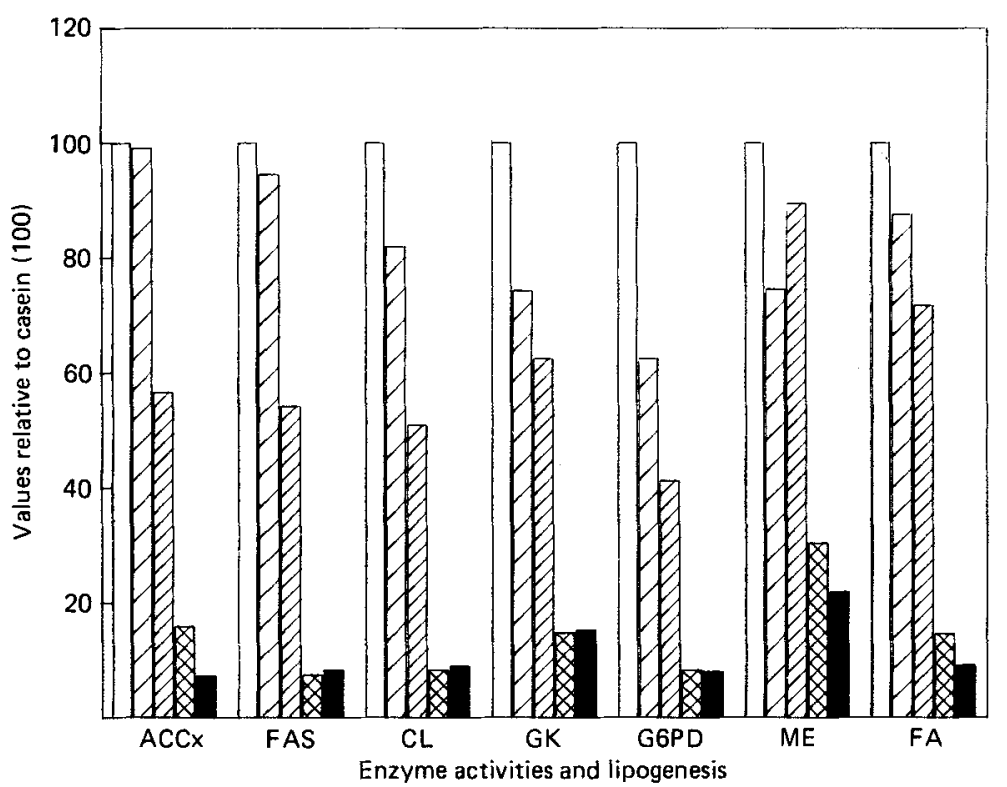

Fig. 3. Total hepatic enzyme activities and lipogenesis in vivo in young rats given proteins of different

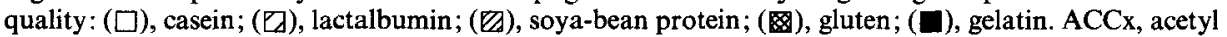
CoA carboxylase (EC 6.4.1.2); FAS, fatty acid synthetase; CL, ATP-citrate lyase (EC 4.1 .3.8); GK, glucokinase ( $E C$ 2.7.1.2); G6PD, glucose-6-phosphate dehydrogenase (EC 1.1.1.49); ME, malic enzyme (EC 1.1.1.40); FA, fatty acid synthesis $\left({ }^{3} \mathrm{H}\right.$ incorporated into saponifiable lipid/liver per $\mathrm{h}$ ). Values are expressed relative to casein (100). The unnormalized values are presented in Table 3.

\section{RESULTS}

The results are summarized in Tables 2 and 3. To make the pattern of the effect of protein quality on lipogenesis more apparent, we have also expressed the results relative to casein. These results are illustrated in Figs. 1-3. Weight gain, feed conversion efficiency ( $g$ weight gained per $g$ feed consumed $\times 100$ ) and protein efficiency ratio (PER; $g$ weight gained per $\mathrm{g}$ protein consumed) all show the same pattern. For each of these measurements of quality, casein was the highest and gelatin the lowest. Between them, in decreasing order, were lactalbumin, soya-bean protein and gluten. DNA expressed per g liver did not vary in any consistent way with protein quality nor did relative liver weight or liver lipid. There was a negative correlation between DNA and lipid both expressed on a per g liver basis $(r-0.93)$.

With the exception of ME and GK all the enzyme activities measured were positively correlated with PER whether specific activity or total activity was measured (correlation coefficients for these were between 0.82 and 0.97 ). Fatty acid synthesis measured in vivo and expressed per $\mathrm{g}$ liver or total liver was also positively correlated with PER $(r$ 0.92). Total ME was positively correlated with PER ( $r 0.92)$; however, ME specific activity was not significantly correlated with PER $(r-0 \cdot 48)$. Total GK was positively correlated with PER $(r 0.96)$ but specific activity was unrelated to PER $(r 0.57)$.

\section{DISCUSSION}

The results presented in the present paper clearly demonstrate a relationship between protein quality and hepatic lipogenesis. We have shown previously that in young rats hepatic lipogenesis is correlated with the protein content of the diet (Herzberg \& Rogerson, 
1981). Thus, whether growth was limited by the amount of protein in the diet or the quality of the protein at a constant content, the faster the weight gain the greater the capacity for hepatic lipogenesis. Two factors contribute to this effect. The increase in total liver lipogenesis and the increase in the total lipogenic enzyme activity is only partly due to the increase in liver size in larger animals. The lipogenic rate per $\mathrm{g}$ liver as well as the specific activities of the enzymes measured, except ME and GK, also increased with the increased growth rate. This was observed in the present study and in our previous work (Herzberg \& Rogerson, 1981). Thus as the growth rate increases, there is an increase in the specific activities of the enzymes involved in hepatic lipogenesis. That this increase does not reflect a general increase in the specific activities of all hepatic enzymes is shown by the activities of GK and ME, which do not change consistently with growth rate.

ME is involved in the generation of NADPH for fatty acid synthesis under a variety of conditions, and usually ME and the other lipogenic enzymes rise and fall in parallel (Gibson et al. 1972; Romsos \& Leveille, 1974; Frenkel, 1975).

However, a number of investigators have reported a dissociation of ME from G6PD or fatty acid synthesis or both. Vaughan \& Winders (1964) gave carbohydrate-free diets containing $400-900 \mathrm{~g}$ protein $/ \mathrm{kg}$ to rats, and observed that while G6PD increased with increasing protein, there was no consistent change in ME. Frenkel and co-workers (Frenkel et al. 1972; Stark \& Frenkel, 1974; Frenkel, 1975; Stark et al. 1975) studied the adaptation that occurs when rats consuming a $100 \mathrm{~g}$ protein $/ \mathrm{kg}$ diet are changed to one containing $5 \mathrm{~g}$ protein $/ \mathrm{kg}$ and observed that while ME was increased, there was no correlation between $\mathrm{ME}$ and fatty acid synthesis in vivo or in vitro. Peret $e$ t al. (1975) found that progressively increasing the dietary protein given to adult rats from 100 to $700 \mathrm{~g} / \mathrm{kg}$ produced a decline in $\mathrm{ME}$ and an increase in G6PD.

Our results with young, growing rats (Herzberg \& Rogerson, 1981; present study) have shown that whether the growth rate is increased by dietary protein content or quality, there is a positive correlation between growth rate and lipogenesis in vivo and ACCx, FAS, G6PD and $C L$, and a negative correlation between growth rate and lipogenesis in vivo and ME. These results clearly demonstrate a dissociation between ME and hepatic lipogenesis and suggest that they have separate regulatory mechanisms.

Our results, combined with those of Peret et al. (1975), suggest that it is not growth rate which regulates G6PD separately from ME but that the supply of essential amino acids may be more important, since Peret et al. (1975) saw the same effect in adult rats given increasing protein as we observed in growing rats. The results of the present study demonstrate that our previous results were not due to changes in the relative proportion of dietary protein and carbohydrate. In the present study the protein and carbohydrate were constant, and we still observed a positive correlation between growth and lipogenesis in vivo and the activities of ACCx, FAS, G6PD and $\mathrm{CL}$ and a dissociation between lipogenesis and ME.

In conclusion, we have examined the effect of dietary protein quality on fatty acid synthesis in vivo and on the activities of a number of enzymes in the liver of young, growing rats. We have observed that fatty acid synthesis and the activities of ACCx, FAS, G6PD and $C L$ increase with increasing protein quality. ME was found to be unrelated to protein quality. These results combined with other reports of dissociation of ME from lipogenesis suggest that they are regulated by separate mechanisms and that ME is not limited to its role in lipogenesis.

This work was supported by the Medical Research Council of Canada (MA-6097). 


\section{REFERENCES}

Frenkel, R. (1975). Current Topics in Cell Regulation 9, 157-181.

Frenkel, R., Stark, M. J. \& Stafford, J. (1972). Biochemical and Biophysical Research Communications 49, 1684-1689.

Gibson, D. M. \& Hubbard, D. D. (1960). Biochemical and Biophysical Research Communications 3, 531-535.

Gibson, D. M., Lyons, R. T., Scott, D. F. \& Muto, Y. (1972). Advances in Enzyme Regulation 10, $187-204$.

Goa, J. (1953). Scandinavian Journal of Clinical Laboratory Investigation 5, 218-222.

Gove, C. D. \& Hems, D. A. (1978). Biochemical Journal 170, 1-8.

Herzberg, G. R. (1983). Advances in Nutrition Research 5, 221-253.

Herzberg, G. R. \& Rogerson, M. (1981). British Journal of Nutrition 45, 529-538.

Herzberg, G. R. \& Rogerson, M. (1982). Canadian Journal of Physiology and Pharmacology 60, 912-919.

Hill, R., Webster, W. W., Linazasoro, J. M. \& Chaikoff, I. L. (1960). Journal of Lipid Research 1, $150-153$.

Lohr, G. W. \& Waller, H. O. (1971). In Methods of Enzymatic Analysis, vol. 2, pp. 636-643 [H. V. Bergmeyer, editor]. New York: Academic Press.

Lowenstein, J. M. (1971). Journal of Biological Chemistry 246, 629-632.

Peret, U., Chanes, M., Cota, J. \& Macaire, I. (1975). Journal of Nutrition 105, 1525-1534.

Pilkis, S. J. (1975). In Methods in Enzymology, vol. 42, pp. 31-39 [W. A. Wood, editor]. New York: Academic Press.

Romsos, D. R. \& Leveille, G. A. (1974). Advances in Lipid Research 12, 97-146.

Srere, P. A. (1959). Journal of Biological Chemistry 234, 2544-2547.

Stark, M. J. \& Frenkel, R. (1974). Life Sciences 14, 1563-1575.

Stark, M. J., Thompson, B. \& Frenkel, R. (1975). Archives of Biochemistry and Biophysics 166, 174-182.

Steel, R. G. D. \& Torrie, J. H. (1960). Principles and Procedures of Statistics. New York: McGraw-Hill.

Vaughan, D. A. \& Winders, R. L. (1964). American Journal of Physiology 206, 1081-1084.

Yeh, Y. Y. \& Leveille, G. A. (1969). Journal of Nutrition 98, 356-366.

Yeh, Y. Y., Leveille, G. A. \& Wiley, J. H. (1970). Journal of Nutrition 100, 917-924. 